\title{
Femtosecond laser-assisted anterior lamellar keratoplasty with suboptimal outcomes: a case series
}

\author{
Ceratoplastia lamelar anterior assistida por laser de femtosegundo \\ com resultados subótimos: uma série de casos
}

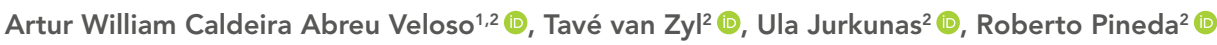

Hospital São Geraldo, Universidade Federal de Minas Gerais, Belo Horizonte, MG Brazil. ${ }^{2}$ Cornea and Refractive Surgery Service, Massachusetts Eye and Ear Infirmary, Harvard Medical School, Boston, MA, USA.

\section{Keywords:}

Corneal transplantation; Keratoplasty, penetrating; Endothelial keratoplasty; Corneal surgery, laser; Keratitis

Descritores: Transplante de córnea; Ceratoplastia penetrante;

Ceratoplastia endotelial; Cirurgia da córnea a laser; Ceratite

Received on: Dec 7, 2020

Accepted on: July 26,2021

Corresponding author: Artur William Caldeira Abreu Veloso Artur William Caldeira Abreu Veloso Otolaryngology Universidade Federal de Minas Gerais Avenida Professor Alfredo Balena, 190 Zip code: 30130-100 - Belo Horizonte, E-mail: arturwilliam_email@yahoo.com.br

Institution: Hospital São Geraldo Universidade Federal de Minas Gerais, Belo Horizonte, MG, Brazil.

Conflict of interest: the authors declare no conflict of interest.

Financial support: the authors received no financial support

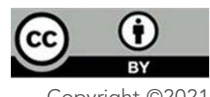

Copyright (๑2021

\section{ABSTRACT}

Objective: To identify preoperative clinical characteristics of patients undergoing femtosecond laser-assisted anterior lamellar keratoplasty who failed to achieve optimal postoperative visual outcomes.

Methods: In this single-center, retrospective case series, patients who underwent femtosecond laser-assisted anterior lamellar keratoplasty between 2013 and 2018 were included if they required graft revision, subsequent corneal procedure, or additional postoperative visits for a femtosecond laser-assisted anterior lamellar keratoplasty-related issue. Visual outcomes assessed included best-corrected visual acuities and postoperative corneal astigmatism.

Results: Eight eyes of eight patients meeting the above criteria were included. Mean patient age was 64.5 years (range, 21 to 89 years). Mean included preoperative best-corrected visual acuities was one logarithm of the minimum angle of resolution (range, 0.3 logarithm of the minimum angle of resolution to counting fingers). Indications for femtosecond laser-assisted anterior lamellar keratoplasty included anterior stromal scarring due to viral keratitis (two cases), bacterial keratitis (one case), chronic epithelial defect (one case), Avellino dystrophy (one case), trauma (one case), and chronic endothelial failure (two cases). Six patients had history of prior intraocular surgeries including phacoemulsification (four cases), pars plana vitrectomy (one case), endothelial keratoplasty (two cases), and trabeculectomy (one case). Mean included best-corrected visual acuities at most recent follow-up was one logarithm of the minimum angle of resolution (range zero logarithm of the minimum angle of resolution to hand movements) representing improvement or stability in six of eight patients. Visually significant corneal astigmatism was present in four of eight patients. Post-femtosecond laser-assisted anterior lamellar keratoplasty procedures included graft repositioning, arcuate keratotomy, phacoemulsification, and regraft.

Conclusion: While femtosecond laser-assisted anterior lamellar keratoplasty offers a less-invasive treatment option compared to penetrating keratoplasty, intraoperative and postoperative management can be complex. Femtosecond laser-assisted anterior lamellar keratoplasty in patients with history of prior endothelial keratoplasty or ongoing ocular comorbidities should be pursued with caution.

\section{RESUMO}

Objetivo: Identificar as características clínicas pré-operatórias de pacientes submetidos à ceratoplastia lamelar anterior assistida por laser de femtossegundo que não alcançaram resultados visuais pós-operatórios ideais. Métodos: Nesta série de casos retrospectiva em um único centro, os pacientes submetidos à ceratoplastia lamelar anterior assistida por laser de femtossegundo entre 2013 e 2018 foram incluídos se precisassem de revisão do enxerto, procedimento corneano subsequente ou visitas pós-operatórias adicionais por uma intercorrência relacionada à ceratoplastia lamelar anterior assistida por laser de femtossegundo. Os resultados visuais avaliados incluíram melhor acuidade visual corrigida e astigmatismo pós-operatório da córnea.

Resultados: Oito olhos de oito pacientes que atenderam aos critérios descritos foram incluídos. A idade média dos pacientes foi de 64,5 anos (variação de 21 a 89). A melhor acuidade visual corrigida pré-operatória média foi de um logaritmo do mínimo ângulo de resolução (variação de 0,3 logaritmo do mínimo ângulo de resolução para contagem de dedos). As indicações para ceratoplastia lamelar anterior assistida por laser de femtossegundo incluíram cicatriz do estroma anterior devido à ceratite viral (dois casos), ceratite bacteriana (um caso), defeito epitelial crônico (um caso), distrofia de Avellino (um caso), trauma (um caso) e insuficiência endotelial crônica (dois casos). Seis pacientes tinham história de cirurgias intraoculares anteriores, incluindo facoemulsificação (quatro casos), vitrectomia via pars plana (um caso), ceratoplastia endotelial (dois casos) e trabeculectomia (um caso). $\bigcirc$ mínimo ângulo de resolução médio no acompanhamento mais recente foi de um logaritmo do mínimo ângulo de resolução (variação de zero logaritmo do mínimo ângulo de resolução para movimentos das mãos), representando melhora ou estabilidade em seis de oito pacientes. Astigmatismo corneano visualmente significativo estava presente em quatro de oito pacientes. Os procedimentos pós-ceratoplastia lamelar anterior assistida por laser de femtossegundo incluíram reposicionamento do enxerto, ceratotomia arqueada, facoemulsificação e enxerto.

Conclusão: Embora a ceratoplastia lamelar anterior assistida por laser de femtossegundo ofereça uma opção de tratamento menos invasiva em comparação com a ceratoplastia penetrante, o manejo intra e pós-operatório pode ser complexo. A ceratoplastia lamelar anterior assistida por laser de femtossegundo em pacientes com história de ceratoplastia endotelial anterior ou comorbidades oculares correntes deve ser avaliada com cautela. 


\section{INTRODUCTION}

Anterior lamellar keratoplasty (ALK) represents the selective replacement of diseased anterior corneal tissue while preserving the posterior stroma, Descemet membrane and endothelium. Primary indications for the procedure can be summarized as anterior corneal dystrophies, scars resulting from trauma or keratitis, or any other condition that is restricted to the anterior stroma. ${ }^{(1)}$ The advantages of ALK over penetrating keratoplasty (PK) have been well reported in the literature, including no endothelial rejection, lower risk of "open sky complications", and a low incidence of anterior synechiae and secondary glaucoma during the postoperative period. ${ }^{(2)}$

Despite these benefits, ALK has not gained popularity due to difficulties related to the surgical technique, which often resulted in interface abnormalities at the recipient-donor stromal junction, often culminating in haze, irregular astigmatism and loss of best corrected visual acuity (BCVA). ${ }^{\left({ }^{3}\right)}$ Also with the advent of phototherapeutic keratectomy (PTK) offering some advantages, like rapid recovery and possibility of repeating the procedure, it was possible to postpone the indication of ALK.(4) Although being an efficient alternative to treat anterior corneal disorders, it is important to note that PTK is limited by the depth of the lesion, possible induction of hyperopia, irregular astigmatism, and haze formation. ${ }^{(4)}$

This scenario changed with the technological advance and introduction of the femtosecond laser in anterior segment surgery, leading to interest in the field of ALK. A new surgical technique called femtosecond laser-assisted

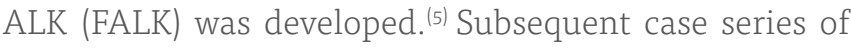
sutureless FALK have reported excellent visual outcomes with minimal postoperative astigmatism. ${ }^{(5-9)}$

In this retrospective study we examined cases in which ideal postoperative visual outcomes were not achieved, with the aim of identifying predisposing preoperative characteristics to help guide future patient selection.

\section{METHODS}

Institutional review board approval was obtained from the Massachusetts Eye and Ear for all aspects of this retrospective case series involving review of patient data and all work complied with the Health Insurance Portability and Accountability Act, and adhered to the tenets of the Declaration of Helsinki. A waiver of consent was granted given the retrospective nature of this study. The electronic medical record was queried to identify all patients undergoing FALK between January 1, 2013 and March 1, 2018, performed by one of two corneal surgeons using the classification of Procedural Terminology code 65710 (anterior lamellar corneal transplant), cross-referenced with an institutional location code corresponding to our femtosecond laser suite. Cases were included in the study if limited chart review revealed at least 90 days of follow up and need for graft revision, subsequent corneal procedure, or additional postoperative visits for a FALK-related issue. Patient demographics, past ocular history and preoperative ocular examination findings including BCVA, manifest refraction (MRx), central corneal thickness (CCT) and depth of stromal opacity, as measured by anterior segment ocular coherence tomography (AS-OCT; Avanti OCT, model RTVue XR 100, Optovue, California, USA), were recorded, as well as intraoperative variables including graft dimensions, suture placement, and concurrent procedures such as PTK. Patients with scarring involving the posterior stroma (more than $250 \mu \mathrm{m}$ of the anterior stroma) or with significant corneal scars totally obscuring visualization of the anterior segment structures were excluded.

Postoperative BCVA, MRx, and graft-related complications were assessed throughout the available follow-up interval. Uncorrected visual acuity (UCVA) and BCVA were measured using a standard Snellen chart and converted to the equivalent logarithm of the minimum angle of resolution (logMAR) value for data analysis. Semiquantitative values for low vision, including counting fingers and hand movements, were assigned logMAR values of $20 / 2000$ and $20 / 3850$, respectively, based on prior validation studies. ${ }^{(10,11)}$

\section{Description of procedure}

Procedures were performed by one of two trained cornea and refractive specialists under topical anesthesia (proparacaine hydrochloride $0.5 \%$ ). Creation of a lamellar cut in the recipient and donor corneas was accomplished using a 150-kilohertz femtosecond laser (IFS, Johnson \& Johnson, California, USA). The femtosecond laser lamellar cuts for the donor corneas were $150 \mu \mathrm{m}$ to $250 \mu \mathrm{m}$, adjusted according to the depth of the scar previously measured by the AS-OCT. The graft sizing cut was as follow: donor lenticule diameter, $7.2 \mathrm{~mm}$ to $8.5 \mathrm{~mm}$ oversized by $0.2 \mathrm{~mm}$ in diameter, compared with the recipient lamellar cut. The host scarred tissue was replaced with the donor lenticule and four anchoring sutures were applied. Adhesion of the host donor interface was tested to certify that graft was well positioned and secured. After the procedure a bandage contact lens was used, which was removed on the 1-week follow-up visit. Patients were administered topical 
antibiotic (fourth-generation quinolones) four times daily, for 1 week, and steroids drops four times daily, which were slowly tapered over a period of 1 to 3 months. If residual scar or a further smoothen of the ocular surface was needed, intraoperative PTK was performed in recipient corneal bed after the femtosecond laser lamellar cut.

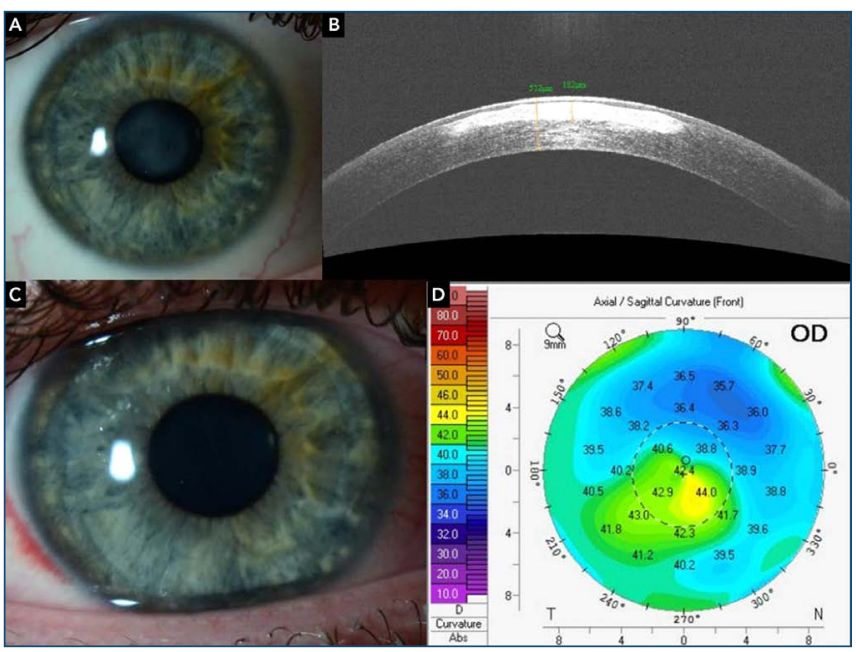

Figure 1. Composite image of slit-lamp photograph (A), anterior segment ocular coherence tomography $(B)$ of right eye preoperative; slit-lamp photograph (C) and Pentacam sagittal curvature map (D) after femtosecond laser-assisted anterior lamellar keratoplasty.

\section{RESULTS}

\section{Patient characteristics}

This study included eight eyes of eight patients undergoing FALK due to anterior corneal scarring and six of them required a second surgical intervention after the primary procedure (Figure 1).

Three of the eight patients had previous anterior corneal scarring due to corneal infections, while two patients were due to chronic endothelial failure, one from corneal dystrophy and two due to previous trauma (chemical and mechanical) (Table 1).

Mean age was $64.5 \pm 20$ years (range 21 to 89 yeras) and mean postoperative follow up was $12.3 \pm 8$ months (range 3.7 to 29.7 months) with a total of five eyes completing their 12-month visit. Mean best spectacle-corrected visual acuity (BSCVA) prior procedure was $20 / 200$ or $1 \pm 0.6$ (range 2.0 to 0.3) logMAR (Table 2).

\section{Adverse effects and need of subsequent procedure}

In six cases a second procedure was needed after primary FALK; in that, one resuture, one deep ALK (DALK) and one astigmatic keratotomy due to high astigmatism, one FALK lift with PTK due to interface haze, one

Table 1. Patient characteristics, preoperative and postoperative femtosecond laser-assisted anterior lamellar keratoplasty outcomes

\begin{tabular}{|c|c|c|c|c|c|c|c|c|c|c|}
\hline Patient & Age & Diagnosis & $\begin{array}{c}\text { Prior } \\
\text { cornea } \\
\text { procedure }\end{array}$ & $\begin{array}{l}\text { Need for } \\
\text { revision in } \\
\text { Laser Suite }\end{array}$ & $\begin{array}{l}\text { Need for } \\
\text { subsequent } \\
\text { surgery }\end{array}$ & $\begin{array}{l}\text { FALK-related } \\
\text { Issue }\end{array}$ & $\begin{array}{l}\text { Postoperative } \\
\text { procedure }\end{array}$ & $\begin{array}{c}\text { Preoperative } \\
\text { BSCVA (logMAR) }\end{array}$ & $\begin{array}{c}\text { Postoperative } \\
\text { BSCVA (logMAR) }\end{array}$ & $\begin{array}{l}\text { Follow-up } \\
\text { (days) }\end{array}$ \\
\hline 1 & 59 & $\begin{array}{l}\text { Corneal ulcer scar } \\
\text { (herpes) }\end{array}$ & None & Yes & No & Decentred graft & $\begin{array}{l}\text { Graft reposition with } \\
\text { sutures }\end{array}$ & 2 & 2 & 112 \\
\hline 2 & 72 & $\begin{array}{l}\text { Avellino corneal } \\
\text { dystrophy }\end{array}$ & None & No & No & $\begin{array}{l}\text { Worsening of } \\
\text { BCVA }\end{array}$ & None & 0.6 & 0.9 & 126 \\
\hline 3 & 89 & $\begin{array}{c}\text { Corneal scar } \\
\text { (after burning), } \\
\text { LagophthalmosVII } \\
\text { palsy }\end{array}$ & AK & No & Yes & None & $\begin{array}{c}\text { Compression sutures } \\
\text { + DALK }\end{array}$ & 1 & 1.3 & 891 \\
\hline 4 & 62 & $\begin{array}{l}\text { Corneal ulcer scar } \\
\text { (herpes) }\end{array}$ & None & Yes & Yes & None & AK & 0.5 & 0.4 & 463 \\
\hline 5 & 21 & $\begin{array}{l}\text { Corneal ulcer scar } \\
\text { (pseudomonas) }\end{array}$ & None & Yes & Yes & None & FALK lift + PTK + suture & 0.3 & 0.3 & 368 \\
\hline 6 & 64 & $\begin{array}{l}\text { Corneal scar after } \\
\text { chronic epithelial } \\
\text { defect, FED stage } 1\end{array}$ & Super K & No & Yes & $\begin{array}{l}\text { Epithelial } \\
\text { ingrowth }\end{array}$ & Phacoemulsification & 0.5 & 0.5 & 300 \\
\hline 7 & 73 & $\begin{array}{l}\text { Anterior stromal } \\
\text { opacity }\end{array}$ & DSEK & No & Yes & Lost graft & PK & 1.3 & 1.2 & 341 \\
\hline 8 & 76 & $\begin{array}{l}\text { PseudoBK, anterior } \\
\text { stromal scarring }\end{array}$ & $\begin{array}{l}\text { DMEK + } \\
\text { PTK }\end{array}$ & No & No & $\begin{array}{c}\text { Chronic epithelial } \\
\text { defect }\end{array}$ & None & 2 & 2.3 & 360 \\
\hline
\end{tabular}

FALK. femtosecond laser-assisted anterior lamellar keratoplasty: BSCVA: best spectacle-corrected visual acuity. logMAR. logarithm of the minimum angle of resolution: BCVA: best corrected visual acuity: AK. astigmatic keratectomy DALK: deep anterior lamellar keratoplasty; PTK: phototherapeutic keratectomy; FED: Fuchs endothelial dystrophy; DSEK: Descemet stripping endothelial keratoplasty; DMEK: Descemet membrane endothelial keratoplasty.

Table 2. Preoperative and postoperative spherical equivalent, cylinder and best spectacle-corrected visual acuity data of femtosecond laser-assisted anterior lamellar keratoplasty

\begin{tabular}{|c|c|c|c|c|c|}
\hline & \multirow{2}{*}{ Preoperative } & \multicolumn{4}{|c|}{ Postoperative } \\
\hline & & 1 month & 3 months & 6 months & 12 months \\
\hline Number of eyes & 8 & 8 & 7 & 6 & 5 \\
\hline Mean spherical equivalent (D) & $-2.8 \pm 3.5(-0.2$ to -8.7$)$ & $-4.8 \pm 5.5(-0.2$ to -11.0$)$ & $-1.5 \pm 3.5(2.5$ to -4.0$)$ & * & * \\
\hline Mean cylinder (D) & $-3.1 \pm 3.0(-0.5$ to -8.0$)$ & $-3.4 \pm 2.2(-2.0$ to -6.0$)$ & $-3.0 \pm 1.73(-2.0--5.0)$ & * & * \\
\hline Mean BSCVA (logMAR) & $1.0 \pm 0.6(2.0-0.3)$ & $1.2 \pm 0.5(2.0-0.5)$ & $1.4 \pm 0.6(2.3-0.6)$ & $1.2 \pm 0.4(2.3-0.4)$ & $1.1 \pm 0.8(2.3-0.3)$ \\
\hline
\end{tabular}

Data presented as mean \pm standard deviation (range); * data not available.

D: diopters; BSCVA: best spectacle-corrected visual acuity; logMAR= logarithm of the minimum angle of resolution. 
phacoemulsification in a previous FALK with epithelial ingrowth, and one PK after a lost graft.

Moreover, in five cases a FALK-related issue was present. In one eye, due to decentered graft, a revision in laser suit was required, with repositioning of the graft and application of anchoring sutures; 3 months after procedure, BSCVA had not improved yet. The second case, a FALK with interface, PTK was indicated due to Avellino corneal dystrophy, however at 4-month follow-up, despite the presence of a clear graft, BSCVA had decreased. The third case had a corneal scar due to a chronic epithelial defect, after a superficial keratectomy, associated with Fuchs endothelial dystrophy grade 1. Femtosecond laser-assisted anterior lamellar keratoplasty with interface PTK was performed, and the patient developed an epithelial ingrowth in the postoperative period. Nevertheless, this case was non-progressive, and patient achieved a visual acuity of 20/20 with aid of contact lens. The forth case had an anterior stromal opacity due to chronic pseudophakic bullous keratopathy, he also had advanced glaucoma and one Descemet stripping endothelial keratoplasty previously performed in that eye. Femtosecond laser-assisted anterior lamellar keratoplasty went uneventfully, but at postoperative day 6 , the patient had a complete lost graft and a subsequent PK was performed. The fifth case similarly had an anterior stromal scarring due to chronic pseudophakic bullous keratopathy and advanced glaucoma. One trabeculectomy, two Descemet membrane endothelial keratoplasties, and one PTK, had been performed prior in the same eye. Later, the FALK patient developed a chronic epithelial defect, which eventually resolved with conservative measures, but not managing to improve visual acuity.

When taking contact lens into consideration, visual acuity improved or remained stable in six of eight eyes, although the mean BSCVA at 12 months was 1.1 \pm 0.6 (2.3 to o.3) logMAR, not statistically significant when comparing with preoperative BSCVA (p-value=0.81, Student's t-test).

\section{DISCUSSION}

From 1914, when Anton Elschnig performed the first lamellar keratoplasty, to 2007, with Hoffart et al.(5) achieving success using femtosecond laser for the procedure, ALK has come a long way. ${ }^{(12)}$ However, since the onset of FALK, the procedure has again attracted interest because of precision and reproducibility provided by the laser, resulting in several reports being published in the literature. ${ }^{(3,13)}$

Enthusiasm with FALK may be explained by the potential accomplishment of the suture-free procedure, ${ }^{(6)}$ because it offers a smoother corneal interface with a higher quality stromal bed. ${ }^{(14)} \mathrm{A}$ growing number of studies have emphasized the success of this surgical technique and reported absence of major complications in a short-term observation period. ${ }^{(3,6,6)}$

Nonetheless, long-term reports have demonstrated procedure-related complications, and some of them were observed in our study. Epithelial ingrowth was one of those complications and it affected one eye, although fortunately it was not visually significant; such complication had been previously described in other studies related to FALK. ${ }^{(7,9)}$

One eye had graft dehiscence after 1 week, which had already been described in a case of femtosecond-assisted deep anterior lamellar keratoplasty. ${ }^{(7)}$ In our study, the patient had previously undergone an endothelial keratoplasty, which may possibly be related to graft loss, since it is postulated endothelial pump function is fundamental for graft apposition, although the tensile force arises with wound healing over time. ${ }^{(15)}$ The osmotic pressure exerted by endothelium in corneal tissue reached $-60 \mathrm{mmHg} .{ }^{(16)}$ Bissen-Miyajima et al. ${ }^{(17)}$ also concluded the endothelium plays an important role in the adhesion of the flap, with the corneal stroma in laser in situ keratomileusis. It was previously defined that a healthy endothelium is one of the necessary conditions for ALK. ${ }^{(18)}$ Although our patient did not show clinical signs of endothelial decompensation prior to FALK, subclinical changes were possibly present, which motivated performing PK after graft loss.

Another patient with previous endothelial keratoplasty had a persistent epithelium defect after FALK. This condition subsequently evolved to a significant subepithelial fibrosis, which had also been previously reported.(7)

Due to an interface haze, one eye was submitted to PTK after graft lift, a complement that has already been documented by other authors. . $3,6,9)^{-}$

In our case series, lamellar separation with the femtosecond laser was successfully achieved regardless of the degree of corneal opacity. Nevertheless, it is important to emphasize patients with significant opacity, which obstructed visualization of the anterior segment, were excluded from the study due to concern that such opacities could disperse the energy of femtosecond laser, compromising the result of the procedure. ${ }^{(6,19)}$

Our postoperative astigmatism mean of $-3.0 \mathrm{D}$ was similar to that obtained by Shousha et al. ${ }^{(9)}$ of $-2.6 \mathrm{D}$, in the sixth month after the operation, and by Mosca et al. ${ }^{(20)}$ of -3.74 D. Anchoring sutures were used to ensure correct positioning of the graft in the recipient bed, thus reducing the risk of decentering in the immediate postoperative period, and being removed during the first follow-up week. 
Compression sutures were used in one case due to high postoperative astigmatism, which evolved to the need to perform DALK for effective astigmatism correction.

Despite these adverse events four of eight patients undergoing FALK had improvement of BCVA commonly with rigid contact lenses; however, potential limitations of our study include a small sample and retrospective design, with no possibility of comparing FALK with other techniques of corneal transplantation to understand the real incidence of procedural-related complications.

In conclusion, FALK seems to be an interesting alternative for diseases affecting the anterior corneal stroma with promising results. However, caution should be exercised in patient selection especially if there are previous endothelial changes. Anchoring sutures may play a role in improving outcome in these cases, although, prospective comparative studies are needed to adequately assess this issue.

\section{REFERENCES}

1. Vajpayee RB, Vasudendra N, Titiyal JS, Tandon R, Sharma N, Sinha R. Automated lamellar therapeutic keratoplasty (ALTK) in the treatment of anterior to mid-stromal corneal pathologies. Acta Ophthalmol Scand. 2006;84(6):771-3.

2. Shimazaki J, Shimmura S, Ishioka M, Tsubota K. Randomized clinical trial of deep lamellar keratoplasty vs penetrating keratoplasty. Am J Ophthalmol. 2002;134(2):159-65.

3. Lu Y, Yang L, Ge Y, Chen X, Huang Z. Femtosecond laser-assisted anterior lamellar keratoplasty for the treatment of stromal corneal pathology. BMC Ophthalmol. 2015;15:15.

4. Deshmukh R, Reddy JC, Rapuano CJ, Vaddavalli PK. Phototherapeutic keratectomy: Indications, methods and decision making. Indian J Ophthalmol. 2020;68(12):2856-66.

5. Hoffart L, Proust H, Matonti F, Catanese M, Conrath J, Ridings B. [Femtosecond-assisted anterior lamellar keratoplasty]. J Fr Ophtalmol. 2007;30(7):689-94.
6. Yoo SH, Kymionis GD, Koreishi A, Ide T, Goldman D, Karp CL, et al. Femtosecond laser-assisted sutureless anterior lamellar keratoplasty. Ophthalmology. 2008;115(8):1303-7.

7. Almousa R, Samaras KE, Khan S, Lake DB, Daya SM. Femtosecond laserassisted lamellar keratoplasty (FSLK) for anterior corneal stromal diseases. Int Ophthalmol. 2014;34(1):49-58.

8. Jabbarvand M, Hashemian H, Khodaparast M, Ghadimi H, Khalilipour E. Femtosecond laser-assisted sutureless anterior lamellar keratoplasty for superficial corneal opacities. J Cataract Refract Surg. 2014;40(11):1805-12.

9. Shousha MA, Yoo SH, Kymionis GD, Ide T, Feuer W, Karp CL, et al. Longterm results of femtosecond laser-assisted sutureless anterior lamellar keratoplasty. Ophthalmology. 2011;118(2):315-23.

10. Lange C, Feltgen N, Junker B, Schulze-Bonsel K, Bach M. Resolving the clinical acuity categories "hand motion" and "counting fingers" using the Freiburg Visual Acuity Test (FrACT). Graefes Arch Clin Exp Ophthalmol. 2009;247(1):137-42.

11. Holladay JT. Proper method for calculating average visual acuity. J Refract Surg. 1997;13(4):388-91.

12. Mannis MJ, Mannis AA, Albert DM. Corneal transplantation: a history in profiles. Oostende, Belgium: JP Wayenborgh; 1999.

13. Bonfadini G, Moreira H, Jun AS, Campos M, Kim EC, Arana E, et al. Modified femtosecond laser-assisted sutureless anterior lamellar keratoplasty. Cornea. 2013;32(4):533-7.

14. Sarayba MA, Ignacio TS, Binder PS, Tran DB. Comparative study of stromal bed quality by using mechanical, IntraLase femtosecond laser 15- and 30kHz microkeratomes. Cornea. 2007;26(4):446-51.

15. Kaufman HE, Insler MS, Ibrahim-Elzembely HA, Kaufman SC. Human fibrin tissue adhesive for sutureless lamellar keratoplasty and scleral patch adhesion: a pilot study. Ophthalmology. 2003;110(11):2168-72.

16. Waring GO III, Bourne WM, Edelhauser HF, Kenyon K. The corneal endothelium; normal and pathologic structure and function. Ophthalmology 1982;89:531-90.

17. Bissen-Miyajima H, Nakamura K, Kaido M, Shimmura S, Tsubota K. Role of the endothelial pump in flap adhesion after laser in situ keratomileusis. $J$ Cataract Refract Surg. 2004;30:1989-92.

18. Hanna KD, David T, Besson J, Pouliquen Y. Lamellar keratoplasty with the Barraquer microkeratome. Refract Corneal Surg, 1991;7:177-81.

19. Yoo SH, Hurmeric V. Femtosecond laser-assisted keratoplasty. Am J Ophthalmol. 2011;151(2):189-91.

20. Mosca L, Fasciani R, Tamburelli C, Buzzonetti L, Guccione L, Mandarà E, et al. Femtosecond laser-assisted lamellar keratoplasty: early results. Cornea. $2008 ; 27(6): 668-72$. 